\title{
Sciendo
}

DOI: 10.1515/aon-2019-0012

\section{SCHEDULING TRANSIT VOYAGES OF VESSELS OF VARIOUS ICE CLASSES ACROSS THE NORTHERN SEA ROUTE}

Tadeusz Pastusiak

Gdynia Maritime University

\begin{abstract}
Main problem for scheduling vessel transit voyages through the Northern Sea Route is the difficulty in predicting distribution of ice boundaries in regions that cannot be overcome by individual ice classes of vessels. Scheduling of voyage is related to speed that vessels can develop and moment of time when vessels will be able to commence and complete passage safely through areas that are main obstacle and are blocking longest transit passage through the Northern Sea Route. This applies to voyages carried out by vessels navigating on their own and with support of icebreakers. Additional problem is lack of consistency of content of maps of ice cover, which can be used for vessels voyage planning through areas where ice cover occurs. Results of this research on influence of uncertain information related with time window of conditions favorable for navigation of vessels of different ice classes on schedule of theirs voyage on example of summer navigation season 2017 are presented in this work.
\end{abstract}

Keywords - Northern Sea Route, ship's ice class, ship voyage schedule

\section{INTRODUCTION}

A significant acceleration in reduction of ice in the Russian Arctic resulted in interest of international maritime carriers. The reason is significant shortening of voyage route between European ports and the Far East compared to traditional route through the Suez Canal. The leading route seems to be attractive but the carriers take into account costs of icebreaking, pilotage, additional insurance and potential unexpected shipping difficulties related to ice conditions occurring on the Northern Sea Route (hereinafter NSR). Sea transport on the NSR in 2015 was estimated at 4 million tones. In contrast, potential transport capacity on this route until 2030 is estimated at 80 million tones. Thus, a 20-fold increase in freight transport is possible (https://vz.ru/economy/2015/6/9/749791.html, date accessed 17.09.2017).

In connection with expected climate changes, the need to increase number of icebreakers in relation to the currently operated and with more drive power than icebreakers currently in use has been noticed [4]. The government of the Russian Federation has secured in state budget expenditure on new-generation nuclear and diesel-powered icebreakers to secure sea transport on the NSR [7]. The will of government of the Russian Federation was upheld in subsequent documents in 2017. The state budget provides for construction of highpower new generation Arctic icebreakers [6].

Results of previous work of the Author [25, 26] indicate systematic extension of time period of occurrence of lighter ice conditions on the NSR, including period favorable to ice-free navigation. It was determined [1, 
$2,11,15]$, that during spring and summer period, when ice melts, vessels should set voyage route in zones with low ice concentration (40-60\%), and if possible - in regions with very low ice concentration (10-30\%) $[21,24]$. Regions with $70-100 \%$ concentration were classified as difficult for ice navigation. For this reason, they should be avoided by vessels. In legal regulations of the Russian Maritime Register of Shipping [29] requirements for ships with different ice and polar classes of vessels are specified. However, the NSR Administration issues special permits also for vessels whose steel hulls do not have ice strengthening. Maritime transport by vessels without ice strengthening is allowed only in ice-free waters [16]. General rule of navigating vessels is practiced by the lightest ice conditions, especially in ice-free or almost ice-free waters, regardless of whether it concerns a low ice-class vessel or icebreaker. Taking above into account, there is a need to examine ice conditions in the recent past, i.e. in 2017 on the Northern Sea Route and their impact on transit shipping of vessels with different ice classes and in particular vessels that do not have ice reinforcements. Important role for scheduling voyage (determination date of beginning, date of end of acceptable for vessel's passage ice conditions and also ice conditions along vessel's route) plays proper designation of ice maps used. Actually available ice maps are made using mostly data from remote sensing methods. Discrepancy in between processed and interpreted satellite image and real ice conditions plays key role in economically scheduled voyage [27]. For this reason more than two sources of ice information should be cross checked during research.

\section{PURPOSE AND SCOPE OF THE WORK}

Purpose of the work is to collect information on ice conditions occurring in 2017 at the NSR and to determine impact of these conditions on possibility of carrying out scheduling transit voyages of vessels with different ice-breaking capabilities. Specific objectives will be:

- determination of boundaries of areas along the vessel's transit route through the NSR, which have at the very least been free of ice and have been closed for ice-free navigation at the earliest,

- determining time course of changes in ice concentration in navigation season,

- determination of time frame in navigation season in which it will be possible to transit through the NSR on vessels with specific ice-breaking capabilities, referred to as ice classes.

Main criterion for ability to pass ice in summer navigation season is concentration of ice [23, 24]. For this reason, selected sources of information on ice concentration will be analyzed. Three groups of sources of information will be selected for analysis in order to verify information content presented on individual maps.

\section{DATA SOURCES}

Among the sources of information on the state of ice cover available on the Internet, there are those that are published by countries with high research activity in the Arctic. These are:

1. Ice concentration analysis maps in simplified Marginal Ice Zone in the Arctic Ocean published by the NIC in georeferenced ERSI Shapefile vector format [3]. These files are available on the NATICE web site (http://www.natice.noaa.gov/products/daily_products.html, date accessed 25.02.2016). They are compiled from various sources of information with a better resolution than 50 meters per pixel. These sources of information include, among others ENVISAT, OLS DMSP, AVHRR i RADARSAT. Analysts carry out necessary interpretation of images. It increases value of these sources for correct identification of ice edge range. Information content is in line with the ice ellipse standard [31, 32], but it has significantly reduced range of information. Total ice concentration scale includes clean water (range 0 to $17 \%$ ), Marginal Ice Zone (range from 18 to $80 \%$ ) and compact ice (range from 81 to 100\%). Maps are published every 24 hours. 
2. Maps of the analysis of ice concentration, ice thickness, ice floe size published by the NIC for selected regions of the Arctic Ocean according to the S-411 standard in geo-referenced vector GML format (http://www.bsis-ice.de/IcePortal/ILP_S411.shtml, date accessed 25.02.2016). Previously published NIC maps were based on analysis and integration of all available data on ice conditions, including weather and oceanographic information and visual observations from shore, ships and planes, aerial radar, satellite images (RADARSAT, ENVISAT, MODIS, GMM) and climate data. Total ice concentration scale includes discrete values $2,13,24,46,68,81$ i $92 \%$. These maps are published every 7 days (168 hours). The specification of the S-411 standard is described in the IHO document [9],

3. Maps of analysis of ice concentration, ice thickness, ice floe size for selected regions of the Arctic Ocean from the PLANETA project in raster JPG format according to the Russian standard for map description [5] convergent with ice ellipses description standard [31, 32] in GIF raster format. In summer season, content of map applies only to concentration of ice. (http://nsra.ru/ru/navigatsionnaya_i_gidrometinformatsiya/icecharts.html, date accessed 25.02.2016). Automatic classification of objects (clusters analysis) from multispectral satellite data using SAR images based on satellite Severyanin is used to develop these maps. Scale of total ice concentration includes discrete values in form of clean water (no ice), 10, 20, 30, 40, 50, 60, 70, 80, 90 and $100 \%$. These maps are published every 4 days (96 hours).

Content of maps published by the PLANETA service includes the most discreet concentration limits. Content of maps in the S-411 standard provided by the NIC includes reduced scope of concentration scale. It seems, however, that it is directly related to operational capability of particular groups of vessels and thus meets the needs of economic activity of vessels in the Arctic. However, content of MIZ type maps published by NIC is significantly reduced. Nevertheless, it meets the needs of vessels that do not have ice strengthening of hull (concentration from $0 \%$ to $17 \%$ ), medium and high ice class vessels without distinction (concentration from $18 \%$ to $80 \%$ ), icebreakers and vessels with the highest ice classes with the support of icebreakers (concentration from $81 \%$ to $100 \%$ ). An important factor indicating timeliness of information content is period of time between consecutive editions of maps [20, 22, 23]. The MIZ type maps are issued by the NIC in the shortest time intervals every 24 hours. The PLANETA project maps are published every 96 hours. Maps in the S-411 standard are issued by the NIC every 168 hours only.

From point of view of the use of ice map files in decision support systems [21, 23, 25] both vector georeferenced files issued by the NIC (type MIZ and S-411 standard) seem to be the most useful due to possibility of direct implementation in computer software like GPS one [10]. Raster format files are more prone to errors and inaccuracies in position and ice concentration readings due to large share of human factor.

\section{RESEARCH METHOD}

The most frequently described type of information regarding state of ice cover in summer navigation season is ice concentration. It defines degree of covering sea surface with ice. It is imaged both in full 10point discrete scale, in form of simplified MIZ scale or in form of an ice boundary with a specific concentration. The MIZ zone plays the most important role for economic human activity in the Arctic. Ice border indicates limit of areas available for ships without hull ice strengthening (not having ice class). As a rule, it is related to $10-18 \%$ of ice concentration, but in extreme cases it concerns limit of up to $35 \%$ of concentration. Therefore, this study will analyze time-space patterns of these ice concentration limits that determine ability to navigate particular groups of vessels with specified ice class [25]. It will therefore be a concentration limit of 10-20\% (for vessels without ice strengthening), concentration limit 24-30\% (for vessels with low ice classes L4), concentration limit 46-50\% (for vessels with medium ice classes L3, L2, L1 and UL), concentration limit 60-68\% (for ships with high ULA ice class) and concentration limit 70-80\% (above 
this concentration, navigation is possible only for icebreakers and ships with a high ice class navigating with support of icebreakers).

\section{RESULTS}

In the first place, the MIZ type ice concentration maps for the year 2017 were analyzed [17]. For predefined limits of concentration of ice available for navigation of vessels of different abilities to overcome ice were determined locations along transit routes of vessels passing through the NSR, which were released from ice the latest and the earliest were closed to ice-free navigation. There were potentially the most difficult ice navigation conditions in them. These were area of the Vilkitsky Strait in the Severnaya Zemlya archipelago, north-eastern part of the Kara Sea and western part of the Laptev Sea (Figures 1a and 1b). For such designated locations, the space-time distributions of ice cover condition in the region constituting the highest difficulty for ice navigation on day of opening (Figure 1a) and closure of the NSR for ice-free navigation (Figure 1b) were studied.

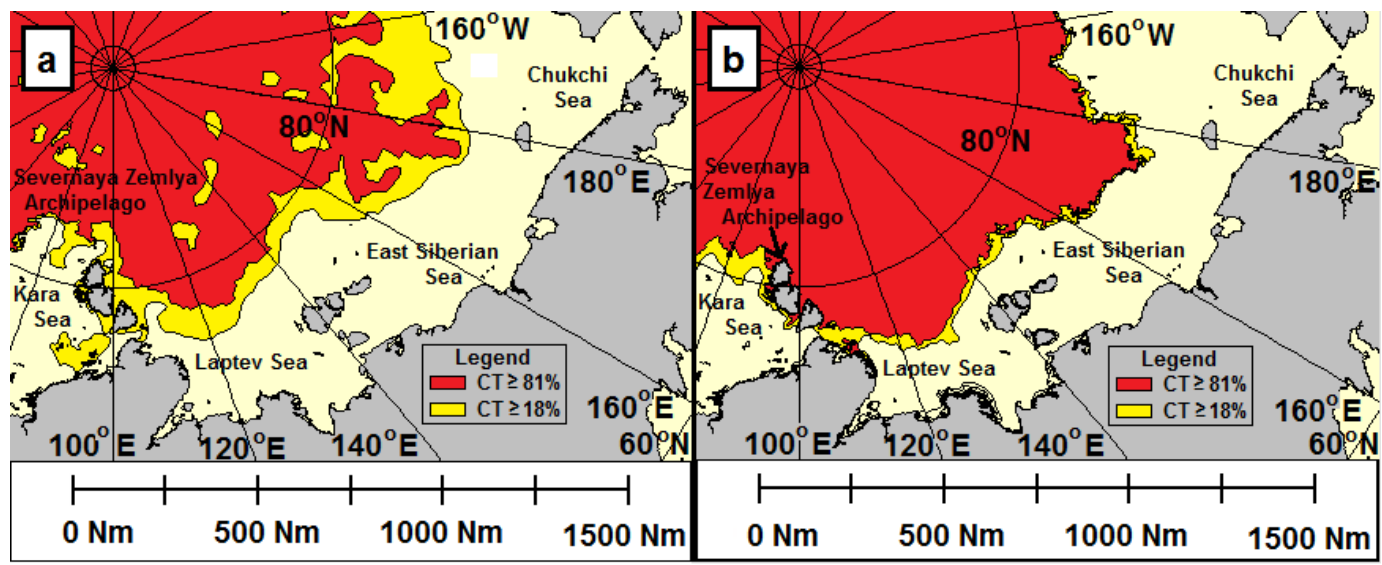

Fig. 1. Geographical distribution of ice on the latest day of inaccessibility of ice free transit zone along the entire NSR at the beginning of navigation season (a) and first day of closing of ice-free transit zone along the whole NSR at the end of navigation season (b). Made by the Author based on [17, 18].

\section{COURSE OF CHANGES IN TOTAL ICE CONCENTRATION IN AREA OF THE VILKITSKY STRAIT AT THE SEVERNAYA ZEMLYA ARCHIPELAGO}

Time course of changes in ice concentration provided by individual sources of information is presented in Figure 2. In analyzed time interval of 2017 year, maps issued by the NIC showed maximum concentration of ice of $80 \%$, while maps issued by the PLANETA showed ice concentration reaching $100 \%$ (Figure 2). Beginning of reduction of ice concentration began in time range from 198 to 208 day of the Julian year ( 198 NIC MIZ, 199 - PLANETA, 208 - NIC S-411). Beginning of ice-free conditions began from 247 to 250th day of the Julian year (247 - NIC MIZ, 248 - PLANETA, 250 - NIC S-411). End of ice-free conditions occurred from 271 to 278 days of the Julian year (271 - NIC MIZ, 276 - PLANETA, 278 - NIC S-411). During period of ice cover growth, the concentration of ice reached maximum values between 273 and 285 days of the Julian year (273 - NIC MIZ, 283 - PLANETA, 285 - NIC S-411).

It has been noticed that series of sampling ice concentration for these ice maps are not always characterized by normal distribution. Due to use of average value and standard deviation, statistical results may be subject to error. Average value is generally used unless there are outliers. In contrast, median is not sensitive to values of samples extremely distant from value of the average.

Medians of individual dates for these three sources of information were respectively 199, 248, 276 and 283 days of the Julian year. On basis of these results, generalized values of durations of reduction of ice concentration from maximum to minimum (49 days), occurrence of ice-free conditions (28 days) and increase 
of ice concentration from minimum to maximum value ( 7 days) were obtained. Time period of concentration increase was 7 times shorter than duration of time period of concentration reduction.

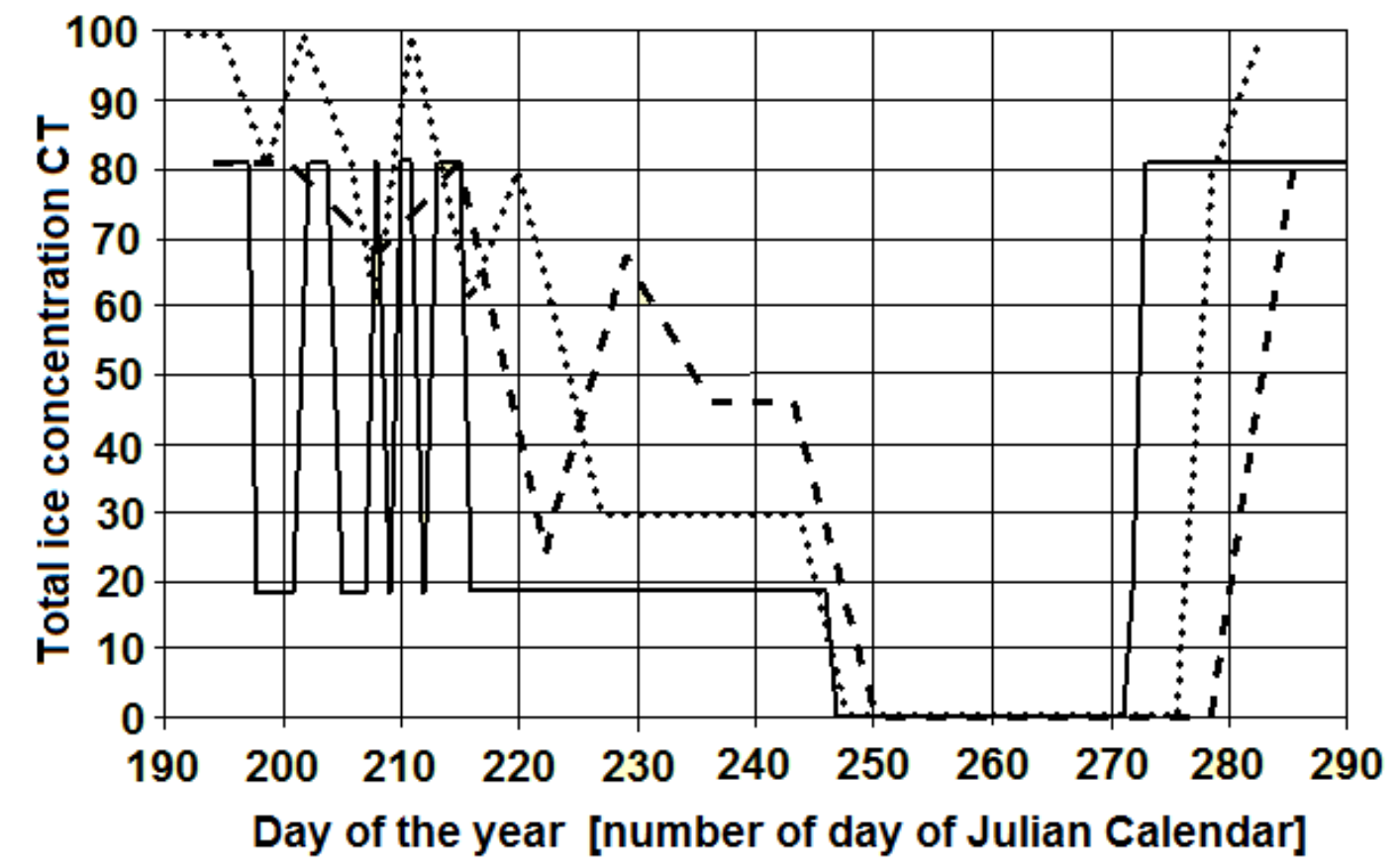

Fig. 2. Time course of changes in ice concentration in area of the Vilkitsky Strait in the Severnaya Zemlya archipelago in 2017; - MIZ type maps issued by the NIC, - - - maps in S-411 format issued by the NIC, $\cdots$ - raster maps published by the PLANETA service. Made by the Author

Next, comparative analysis of mean and median values for individual values of total ice concentration in the studied region and the studied time interval of the 2017 navigation season for the analyzed ice maps was carried out. For this purpose, average value of date of successive ice concentrations and their standard deviation as well as median (center value as second quartile), lower (first) quartile and upper (third) quartile were calculated for entire period of ice cover reduction and growth). Lower (first) quartile $\mathrm{Q}_{1}$ is median of subsample consisting of "half" of the smallest elements of set of samples, i.e. all samples of the set of samples, in not descending order, which precede median Me. Upper (third) quartile of $\mathrm{Q}_{3}$ is median of subsample consisting of "half" of the largest elements of set of samples, i.e. all elements of set of samples sorted in not descending order, which occur after median. The results of calculations were presented in Table 1.

Table 1. Deviations of ice concentration from values of reference for three analyzed ice maps together

\begin{tabular}{|c|c|c|c|}
\hline Feature & $\begin{array}{c}\text { Standard } \\
\text { deviation } \sigma \\
\text { [days] }\end{array}$ & $\begin{array}{c}\text { Deviation of first } \\
\text { quartile Q1 from median } \\
\text { Me [days] }\end{array}$ & $\begin{array}{c}\text { Deviation of third quartile } \\
\text { Q3 from median Me [days] }\end{array}$ \\
\hline $\begin{array}{c}\text { Maximum value of } \\
\text { deviations [days] }\end{array}$ & \pm 13.1 & -10.5 & +11.5 \\
\hline Median of deviations [days] & \pm 6.1 & -4 & +5.5 \\
\hline $\begin{array}{c}\text { Minimum value of } \\
\text { deviations [days] }\end{array}$ & \pm 0 & -0 & +0 \\
\hline
\end{tabular}

It should be noted that time interval $\pm \sigma$ refers to probability of $68.3 \%$ and time interval from first to third quartile refers to probability of 50\%. Received results confirm that distribution of changes in ice concentration over time is not normal. Standard deviation "averages" deviations below and above mean value. Deviations of first and third quartiles from median value show greater concentration of samples from side of smaller values than on side of larger values than median. It was assumed that median and quartile values better reflect 
statistical distribution (distribution of geographical positions) of samples. In connection with above, data on median and quartiles were analyzed in further part of this work.

For median value of total ice concentration, distribution of changes was analyzed during summer navigation season in the studied region for analyzed all three sources of information (Figure 3). Found slower decrease of ice concentration during ice decay and quick increase of ice concentration during its development. During period of ice decay, for concentrations below $60 \%$, data provided by the National Ice Center (NIC) show noticeably lower concentration than other two sources of ice information. Data provided on maps in S411 standard show significant variability of concentration. However, this concentration is always higher than on maps published by the NIC. Maps published by the PLANETA website do not seem to take into account periodic changes in ice concentration. It looks like "averaging" or "simplify" data provided on maps in S-411 standard. During ice cover growth period, data provided by all three sources of information are convergent (Figure 3) and errors are within limits of deviations given in Table 1.

For designated ice concentration limits (Figure 2) allowing navigation of vessels with specific ice-breaking capabilities, median of day of the Julian year for all three analyzed sources of information was calculated. Limit values of ice concentration depicted on particular maps did not overlap or were not depicted on individual maps. Due to above, median value was result of data from three, two or even only one source of information. Despite this, results proved to be consistent. So obtained graph (Figure 4) shows that duration of navigation season for vessels of high ice class navigating on the NSR with icebreaker support is more than twice as long as for vessels not adapted to navigation in ice. Period of time when ice concentration increased from 0 to $81 \%$ was only 3 days. Due to lack of data for concentration values between 0 and $81 \%$, it should be assumed that on the day of first autumn ice appearance, all commercial vessels, including vessels with high ice classes, should leave area under investigation in the Severnaya Zemlya archipelago.

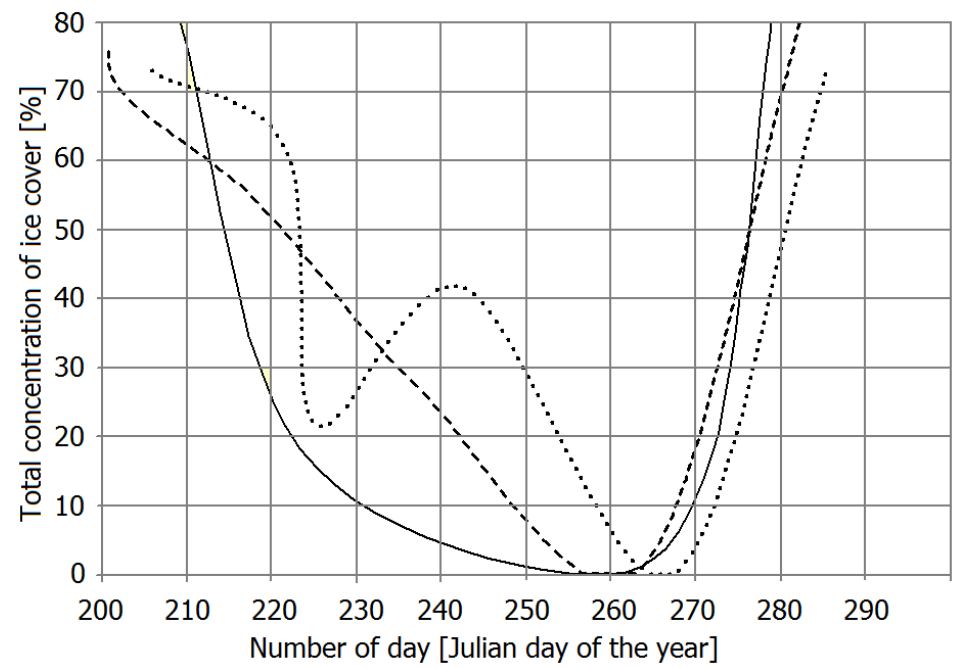

Fig. 3. Time distribution of changes in ice concentration in area of the Vilkitsky Strait in the Severnaya Zemlya archipelago on basis of median value; — according to MIZ type maps issued by the NIC, - - - according to maps published by the PLANETA service, $\cdots$ according to maps of S-411 standard issued by the NIC. Made by the Author. 


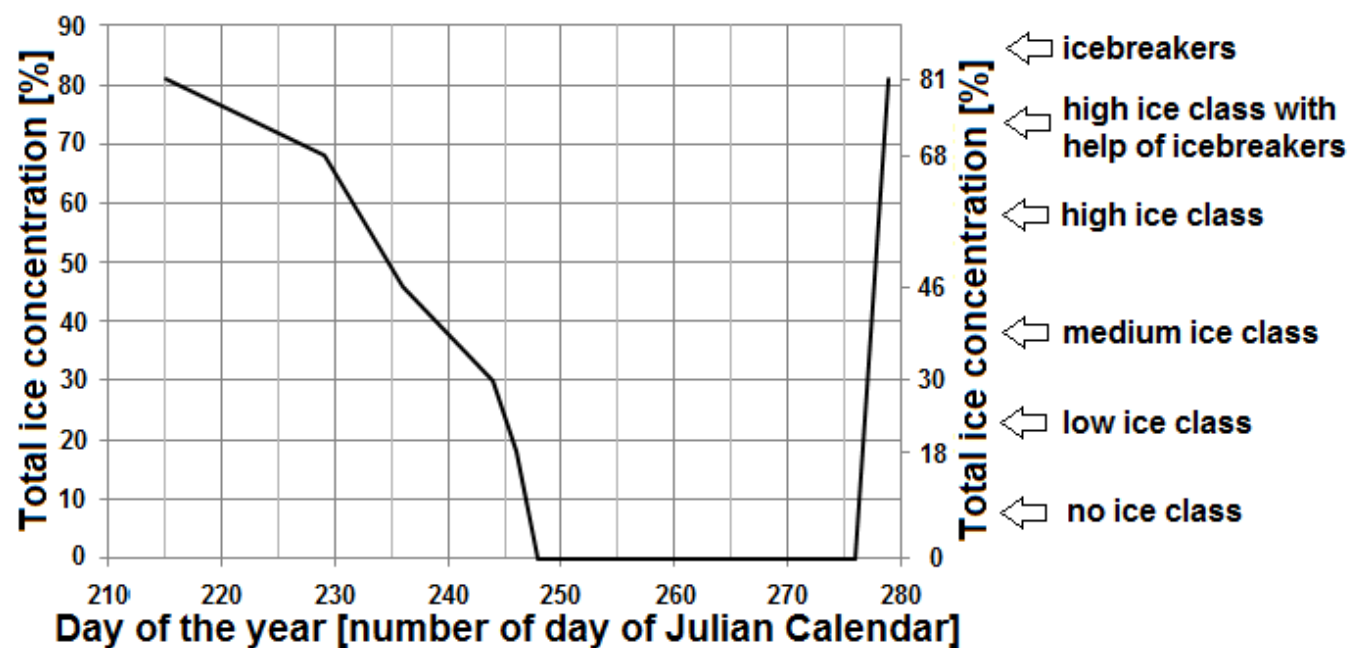

Fig. 4. Median ice concentration in the studied region for all three sources of information taken together and time frame of navigation season for vessels with specific ice-breaking capabilities (ice classes). Made by the Author.

Graphs of ice concentration in Figure 2 were read directly from maps of three different producers obtained by satellite remote sensing methods. Impact of possible terrestrial observations, applied data processing algorithms and in particular added value due to work of experienced researchers on final form of maps was different $[20,21,23]$. Therefore, it is difficult to make such comparisons between analyzed maps. It was observed that time window available for transit voyages on the NSR for particular ice classes read from graphs obtained by different methods (figures 2, 3, 4) are not fully compliant. Graphs in Figure 2 were obtained on basis of direct reading of concentration values on maps. Graphs in Figures 3 and 4 are based on various statistical calculation methods.

Time window, for example, for ships not having ice strengthening, which corresponds to presence of ice concentration not exceeding 18\%, begins in graph in Figure 2 on 216 (NIC MIZ), 247 (NIC S-411), 245 (PLANETA) and lasts 57 (NIC MIZ), 34 (NIC S-411), 32 (PLANETA) days. In Figure 3, time window begins on day 223 (NIC MIZ), 254 (NIC S-411), 243 (PLANETA) and lasts 50 (NIC MIZ), 21 (NIC S-411), 28 (PLANETA) days. In contrast, in Figure 4, time window begins on 246 and lasts 32 days (Table 2). So, discrepancies in results obtained by various statistical methods based on different ice maps are significant. Median of all results (beginning, end and period of time frame) is most often very convergent with nonstatistically processed data contained on the PLANETA maps. Results obtained on basis of maps of the S-411 standard issued by the NIC show the greatest variability (dispersion). On other hand, results for vessels without ice strengthening obtained on basis of MIZ type maps published by the NIC show the least variability regardless of statistical method used, if such method does not combine information from maps of different producers (Table 2, Figures 2 and 3). Length of time window for ice concentration not higher than 18\% (the length of navigation season for ice-free navigation conditions) for the PLANETA maps and median results of all methods and sources of information is highly convergent with results of Frolov et al. [4] and earlier work of the Author [19] related to very light ice conditions. 
Table 2. The dates of beginning, end and duration of time window obtained by various statistical methods. Made by the Author.

\begin{tabular}{|c|c|c|c|c|}
\hline \multirow{4}{*}{ Reference } & Ice map & $\begin{array}{c}\text { Beginning } \\
\text { [number of Julian day] }\end{array}$ & $\begin{array}{c}\text { End } \\
\text { [number of Julian day] }\end{array}$ & $\begin{array}{c}\text { Time frame } \\
\text { [number of Julian day] }\end{array}$ \\
\cline { 2 - 5 } & NIC MIZ & 216 & 272 & 57 \\
\cline { 2 - 5 } & NIC S-411 & 247 & 280 & 34 \\
\cline { 2 - 5 } & PLANETA & 245 & 276 & 32 \\
\hline \multirow{3}{*}{ Fig. 3 } & NIC MIZ & 223 & 272 & 50 \\
\cline { 2 - 5 } & NIC S-411 & 254 & 274 & 21 \\
\cline { 2 - 5 } & PLANETA & 243 & 270 & 28 \\
\hline Fig. 4 & All in one & 246 & 277 & 32 \\
\hline Mediana & All together & 245 & 274 & 32 \\
\hline
\end{tabular}

\section{SPATIAL DISTRIBUTION OF ICE COVER BEFORE OPENING OF THE NSR FOR ICE-FREE NAVIGATION IN AREA OF THE VILKITSKY STRAIT IN THE SEVERNAYA ZEMLYA ARCHIPELAGO}

Based on general location of ice massifs in the Arctic Ocean [12,30] and location of ice formations in summer season $[8,13,28]$, possible limits of minimum ranges of ice massifs around the Severnaya Zemlya archipelago were determined (Figure 5). Region constituting a bottleneck and therefore difficult to navigate was found along northern coast of Taymyr peninsula between longitude $105^{\circ} \mathrm{E}$ and $112^{\circ} \mathrm{E}$ (Figure 5). For its passage, vessels should navigate section of route, approximately 85 Nautical miles long. This place corresponded to location of southwestern part of the Taymyr ice massif. Second place that was obstacle to navigation was western part of the Vilkitsky Strait between Bolshevik Island and the Nordenskiöld Archipelago. It is region of occurrence of the Severnaya Zemlya ice massif.

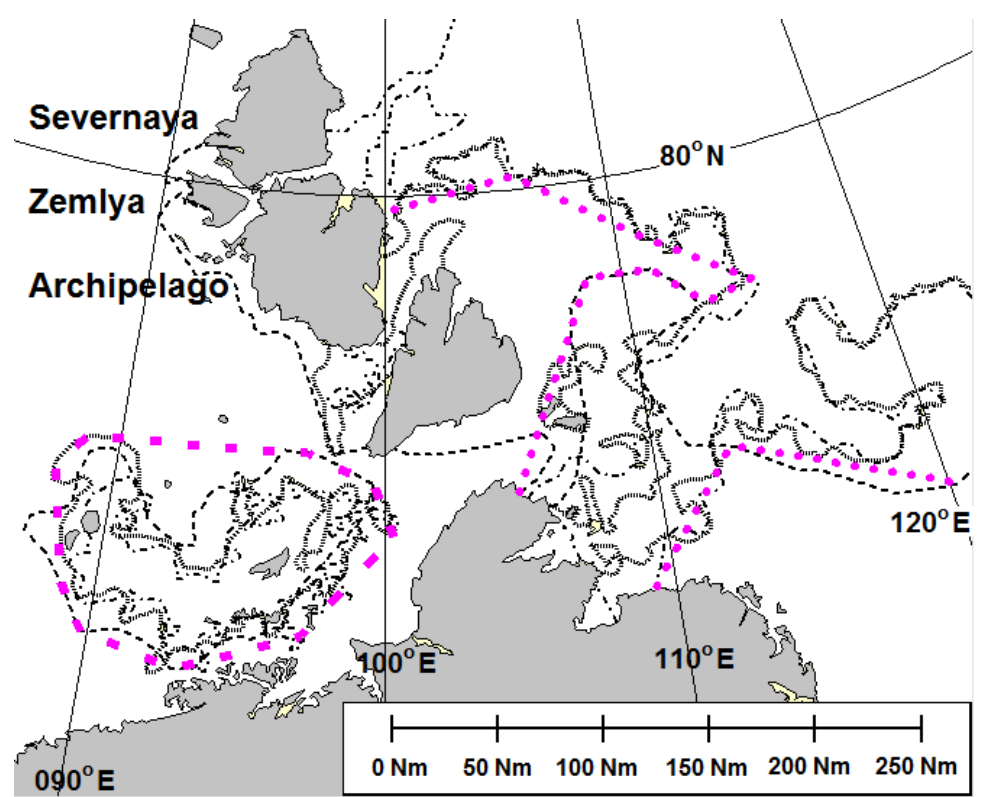

Fig. 5. Spatial distribution of ice cover before opening of the NSR for ice-free navigation in area of the Vilkitsky Strait in the Severnaya Zemlya archipelago; - - - NIC MIZ ice boundary, - - - PLANETA ice boundary, |||||||||||| - NIC S-411 ice boundary, - approximate external ice limit on all maps. Made by the Author based on [17, 18].

Next, courses of selected limits of ice concentration were analyzed, which formed belts of ice with higher concentration than surrounding ice, between the Taymyr Peninsula and highly concentrated ice in the southwestern part of the Laptev Sea. They created an obstacle for vessels moving on only ice-free passage between the Kara Sea and the Laptev Sea through the Vilkitsky Strait. It was concentration limit of $18 \%$ for 
NIC MIZ maps, 30-100\% for maps published by the PLANETA service and 13\% for NIC maps of S-411 standard (Figure 5).

Length of these sections amounted to 12 Nautical miles on the NIC MIZ maps (on day 246), 6 Nautical miles on the NIC S-411 maps of (on day 243) and for map issued by the PLANETA service reached 28 Nautical miles (on day 244). Western and eastern courses of borders of selected concentrations on the NIC S411 ice maps and maps published by the PLANETA service were very similar. Location of center of higher concentration of ice on the NIC MIZ maps was shifted to the west by approximately 40-50 nautical miles from the belt depicted on the NIC S-411 map and the map published by PLANETA service.

\section{SPATIAL DISTRIBUTION OF ICE COVER AFTER THE NSR WAS CLOSED FOR ICE- FREE NAVIGATION IN THE AREA OF THE VILKITSKY STRAIT IN THE SEVERNAYA ZEMLYA ARCHIPELAGO}

Region constituting a bottleneck and therefore difficult to navigate was found along northern coast of Taymyr Peninsula between longitude $103^{\circ} \mathrm{E}$ i $117^{\circ} \mathrm{E}$ (Figure 6). For its passage, vessels should navigate a section of route, approximately 200 Nautical miles long. This place corresponded to location of southwestern part of the Taymyr ice massif.

Next, courses of selected limits of ice concentration were analyzed, which formed belts of ice cover with higher concentration than surrounding ice, between the Taymyr Peninsula and areas of very high concentration of ice in southwestern part of the Laptev Sea. They created an obstacle for vessels moving on only ice-free passage between the Kara Sea and the Laptev Sea through the Vilkitsky Strait. It was concentration limit of $18 \%$ for NIC MIZ maps, $50-80 \%$ for maps published by the PLANETA service and $81 \%$ for NIC maps of S-411 standard (Figure 6).

Length of these sections was 105 Nautical miles (on day 272) on NIC MIZ maps, 120 Nautical miles (on day 255) on NIC S-411 maps and for the maps published by the PLANETA service was 163 Nautical miles (on day 279). Western and eastern borders of selected concentration of ice cover and map producers were similar. The only major derogation concerned western border of the NIC S-411 maps and eastern border of the NIC MIZ type maps, which were displaced into zone of higher ice concentration. The characteristic indentation of eastern border of ice into zone of higher concentration was noticeable on each of three types of analyzed maps.

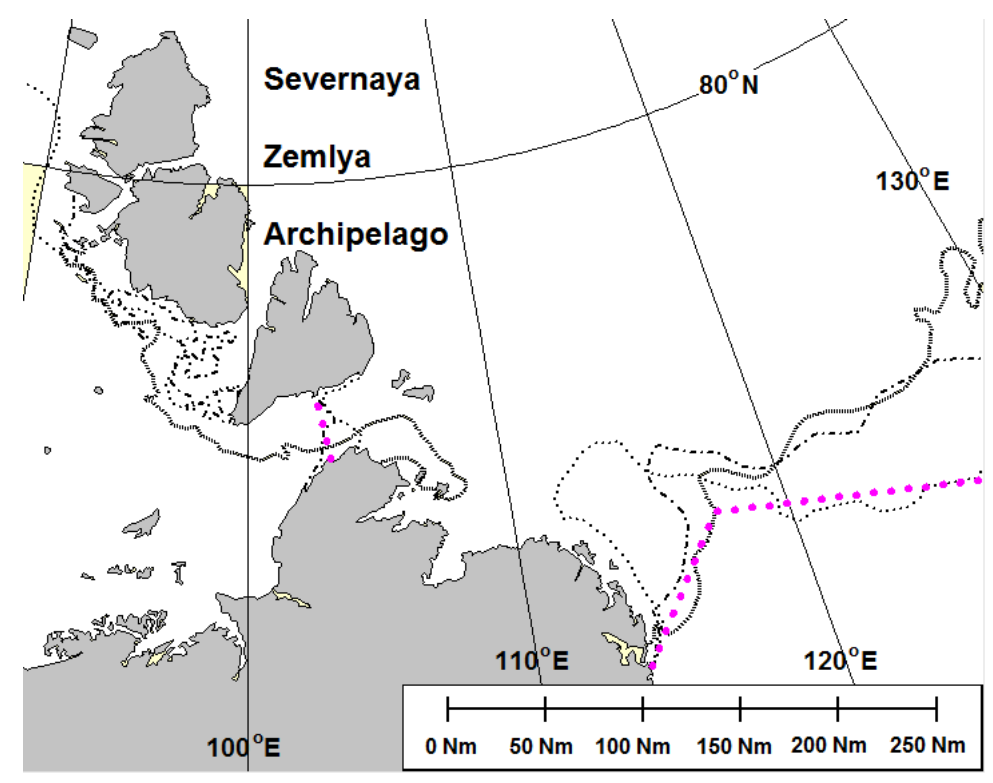


Fig. 6. Spatial distribution of ice cover after the NSR closed for ice-free navigation in area of the Vilkitsky Strait in the Severnaya Zemlya archipelago; - - - NIC MIZ ice boundary, • - • - PLANETA ice boundary, ||||||||||||| - NIC S-411 ice boundary, घ = ! approximate external ice limit on all maps. Made by the Author based on 17, 18].

\section{DISCUSSION OF RESULTS AND CONCLUSIONS}

Ice concentration maps used for analysis come from different producers. They use different discrete ice concentration scales and they are issued at various intervals (every 24, 96 or 168 hours). Even content of maps published by the same National Ice Center producer in the United States, i.e. MIZ type maps and maps developed according to S-411 standard for the same day did not show identical geographical distribution of individual ice concentration limits. Assumed that this was the result of different research methods carried out by different research teams. Ice concentration limits on maps issued by different producers for the same reference days could not be directly compared because they did not use identical discrete scales of concentration. Different time intervals of publication of subsequent editions of maps from different producers caused that analyzed maps did not refer to the same day of ice cover analysis.

For above reasons, analysis of geographic patterns of ice boundaries carried out in this work did not compare the closest ice concentration limits used in contents of analyzed maps, but focused on comparison of concentration boundaries forming ice zone making it difficult to navigate between the Kara Sea and the Laptev Sea through the Vilkitsky Strait. Despite discrepancy of publication dates and various analyzed ice concentration limits, course of borders forming zone of higher concentration from continental coast to very high concentrated ice in the Arctic Ocean showed significant convergence. This made it possible to determine location of the most difficult ice conditions in the 2017 navigation season on the Northern Sea Route. Such zone of difficult ice conditions during opening of the NSR seas for ice-free navigation and during closing of these seas was region of the Severnaya Zemlya archipelago in eastern part of the Vilkitsky Strait, adjacent to continental Taymyr Peninsula in western part of the Laptev Sea. It was area where the Taymyr ice massif occurred. Length of zone that obstructed navigation with merchant vessels before opening of the NSR seas for ice-free navigation was 85 Nautical miles and at beginning of closing of the NSR seas was 200 Nautical miles.

Second zone of difficult ice conditions occurring during opening of the NSR seas for ice-free navigation was western part of the Vilkitsky Strait between the Bolshevik Island and the Nordenskiöld Archipelago. It was region of occurrence of the Severnaya Zemlya ice massif. The above results are consistent with the results of the Author's earlier research [26]. It was determined then that the highest possible difficulties for shipping (the smallest numbers of ice-free days) occurred in 2008-2016 in the Laptev Sea (minimum of 0.0 days with an average of 37.1 days) and in the Kara Sea (minimum 12 days) at an average of 50.3 days). Ice conditions prevailing in 2017 in area of the Severnaya Zemlya archipelago and area of the Laptev Sea are also in line with results of works of Marsz et al. [14]. It was shown there that the highest values of ice covered surface of seas lying along the NSR occurred in the Laptev Sea (3-60\%). So, in recent years, this was a region that potentially poses the greatest ice difficulties for transit navigation through the NSR. Due to publication of maps of individual producers at various time intervals, it was impossible to make precise comparison of dates and individual concentrations of ice borders in full range of division of vessels in terms of ice-breaking capacity. For this reason, only median dates of beginning of reduction of ice concentration, beginning of icefree conditions, end of ice-free conditions and first time of maximum ice concentration values for the three sources of information were determined. They amounted to 199, 248, 276 and 283 days of the Julian year, respectively. On this basis generalized values of durations of reduction of ice concentration from maximum to minimum (49 days) at ice melting period, occurrence of ice-free conditions ( 28 days) and increase of ice concentration from minimum to maximum value (7 days) at ice growth period were determined. Time of reduction of ice concentration was 7 times longer than duration of concentration increase from minimal to maximal. 
Dates of beginning, end and duration of time window obtained by various statistical methods for vessels without ice strengthening (ice concentration not exceeding 18\%) for different combinations of ice maps do not give clear result. Median beginning, end and period of time frame was very convergent with not statistically processed data contained on PLANETA maps. The results obtained on basis of maps of S-411 standard issued by the NIC show the greatest dispersion. Results obtained on basis of MIZ type maps published by the NIC show the smallest variability regardless of applied statistical method, if such method does not combine information from maps of different producers. Length of time window for ice concentration not higher than $18 \%$ (length of navigation season for ice-free navigation conditions) for the PLANETA site maps, median results of all methods and sources of information are highly convergent with results of works of Frolov et al. [4] and results of the Author's previous work [19] for very light ice conditions.

In spite of small number of input data on borderline ice concentrations allowing navigation of vessels with specific ice-breaking capacities and median on the Julian year meeting above criteria, consistent results were obtained. Duration of navigation season for vessels of high ice class sailing on the NSR with icebreaker support was more than twice as long as for vessels not adapted to navigation in ice. Time of ice concentration increase from 0 to $81 \%$ was only 3 days at the period of ice growth. It should be assumed that on the day of first autumn ice impeding transit voyages from northern part of the continental coast of Taymyr Peninsula to the region of very high concentration in the Arctic Ocean, all commercial vessels up to high ice classes should leave the area under investigation in the Severnaya Zemlya archipelago.

Differences in quality of map content seem to have relatively small impact on usefulness of source of information. Uncertainty of position of described parameter looks to have higher impact on usefulness of map content. However assumed, map resolution being analyzed was acceptable. Frequency of publishing subsequent editions of map had the greatest impact on usefulness of map content. It seems that ice maps published every 96-168 hours, despite more precise scale of concentration than MIZ type maps, do not make it possible to set dates of beginning and end of ice-free navigation period with satisfactory accuracy for planning and scheduling of voyage of vessels without ice strengthening. Research results indicate that precision of vessel voyage scheduling on the NSR can be improved by appropriate selection of statistical methods used to determine date of opening and closing of zone of higher ice concentration and same way is creating particular difficulty for maritime transport.

\section{REFERENCES}

[1] Arikaynen A.I., 1990. Navigation in the Arctic ice [in Russian] (Судоходство во льдах Арктики). Transport, Moscov.

[2] Arikaynen A.I., Tsubakov K.N., 1987, Alphabet of ice navigation. [in Russian] (Азбука ледового плавания). Transport, Moscov.

[3] ESRI, 1998, ESRI Shapefile Technical Description. An ESRI White Paper-July 1998, Environmental Systems Research Institute.

[4] Frolov I.E., Gudkovich Z.M., Karklin V.P., Smolyanitsky V.M., Kliachkin S.V., Frolov S.V., 2016. Part 10. Sea ice [in Russian] (Глава 10. Морской лёд, http://docplayer.ru/docview/17/76851/\#file=/storage/17/76851/76851.pdf [Date accessed 24.09.2017].

[5] Gidrometeoizdat, 1974, Nomenclature of sea ice, symbols for ice maps [in Russian] (Номенклатура морских льдов, условные обозначения для ледовых карт), electronic version available on web site http://www.aari.ru/gdsidb/glossary/nsimvol.htm, [Date accessed 08.09.2014].

[6] GRF, 2017, Resolution of the Government of the Russian Federation of March 31, 2017 No. 374 "On Amending the Decree of the Government of the Russian Federation of April 15, 2014 No. 304", 
Government of Russian Federation [in Russian] (Постановление Правительства РФ от 31 марта 2017 г. N 374 "О внесении изменений в постановление Правительства Российской Федерации от 15 апреля 2014 г. N 304")

[7] GRF, 2014, Approval of 21 April 2014 No. 366 Moscow, On the approval of the state program of the Russian Federation "Socio-economic development of the Arctic zone of the Russian Federation for the period up to 2020", Government of Russian Federation [in Russian] (Об утверждении государственной программы Российской Федерации "Социально-экономическое развитие Арктической зоны Российской Федерации на период до 2020 года")

[8] GUNiO, 1996, The guide to navigating through the northern sea route. GUNiO, no 4151B.

[9] IHO, 2014, Ice Information Product Specification, JCOMM S-411, Monaco.

[10] IHO, 2010, Facts about electronic charts and carriage requirements, IHO publication S-66, Edition 1.0.0 - January 2010, International Hydrographic Bureau, Monaco.

[11] Khvochtchinski N.I., Batskikh Yu.M., 1998, The Northern Sea Route as an element of the ICZM system in the Arctic: problems and perspectives. Elsevier, Ocean \& Coastal Management 41 (1998).

[12] Kitagawa H., 2001, The Northern Sea Route. The shortest sea route linking East Asia and Europe. Ship \& Ocean Foundation, ISBN 4-88404-027-9, Tokyo, Japan.

[13] Marchenko N., 2012, Russian Arctic Seas. Navigational conditions and accidents. Springer-Verlag, Berlin-Heidelberg.

[14] Marsz A.A., Pastusiak T., Styszyńska A., 2014, Changes of sea ice extent on the Euro-Asiatic Arctic seas linked to potential of navigation on the Northern Sea Route in the second decade of XXI century [in Polish] (Zmiany powierzchni lodów na morzach eurazjatyckiej Arktyki i ich potencjalny wpływ na nawigację na Północnej Drodze Morskiej w drugiej dekadzie XXI wieku), Problemy Klimatologii Polarnej, no. 24.

[15] Mironov E.U.(ed), Frolov S.V., Klyachkin S.V., Gudkovich Z.M., May R.I., Benzeman V.Y., Adamovich N.M., Gorbunov Y.A., Losev S.M., Dyment L.N., Buzin I.V., Egorov A.G., Yulin A.V., Panov V.V., Lavrenov I.V., Pasechnik T.A., Dymov V.I., Yakovleva N.P., 2010, Dangerous ice phenomena for navigation in the Arctic. [in Russian] (Опасные ледовые явления для судоходства в Арктике). AANII, St. Petersburg.

[16] MTR, 2013, Rules of navigation on the water area of the Northern Sea Route. Approved by the order of the Ministry of Transport of Russia dated January 17, $2013 \_7$.

[17] NATICE, 2017, Ice concentration maps in ESRI Shape format, (http://www.natice.noaa.gov/Main_Products.htm), [Date accessed 10.11.2017], Provided courtesy of the U.S. National Ice Center.

[18] Natural Earth, 2017, Free vector and raster map data at 1:10m, 1:50m, and 1:110m scales. (http://www.naturalearthdata.com), [Date accessed 01.01.2017].

[19] Pastusiak T., 2018, Planning route of vessel for "ice-free" navigation conditions on the Northern Sea Route [in Polish] (Planowanie samodzielnych podróży tranzytowych statku bez wzmocnień lodowych przez Północną Drogę Morską), Wydawnictwo Akademii Morskiej w Gdyni.

[20] Pastusiak T., 2016a, Accuracy of Sea Ice Data from Remote Sensing Methods, its Impact on Safe Speed Determination and Planning of Voyage in Ice-Covered Areas, TRANSNAV - International Journal of Marine Navigation and Safety of Sea Transportation, No. 2/2016. 
[21] Pastusiak T., 2016b, Consistency of data presented on modern maps of ice cover in the Arctic, Polish Cartographical Review, No. 2/2016.

[22] Pastusiak T., 2016c Functionality of Sea Ice Data Sources on the NSR, TRANSNAV - International Journal of Marine Navigation and Safety of Sea Transportation, No. 3/2016.

[23] Pastusiak T., 2016d, Nautical electronic maps of S-411 standard and their suitability in navigation for assessment of ice cover condition of the Arctic Ocean, Polish Cartographical Review, No. 1/2016.

[24] Pastusiak T., 2016e, Principles of vessel route planning in ice on the Northern Sea Route, TRANSNAV - International Journal of Marine Navigation and Safety of Sea Transportation, No. 4/2016.

[25] Pastusiak T., 2016f, The Northern Sea Route as a shipping lane. Expectations and Reality. ISBN 9783-319-41832-2, ISBN eBook 978-3-319-41834-6, Springer International Publishing AG, Switzerland.

[26] Pastusiak T., 2016g, Changes in „Ice-free” navigation season on the Northern Sea Route in the years 2008-2016 [in Polish] (Zmiany czasu trwania żeglugi w warunkach „bezlodowych” na Północnej Drodze Morskiej w latach 2008-2016), Problemy Klimatologii Polarnej, no. 26, Warszawa.

[27] Pastusiak T., 2014, Planowanie trasy statku dla warunków żeglugi „,bezlodowej” na Północnej Drodze Morskiej, Prace Wydziału Nawigacyjnego Akademii Morskiej w Gdyni, Nr 29.

[28] Ragner C.L., 2000, Northern Sea Route Cargo Flows and Infrastructure-Present State and Future Potential. The Fridtjof Nansen Institute, Report 13 (2000).

[29] RMRS, 2016, Rules for the classification of sea-going ships. Part. 1, Classification, Electronic version of printed document approved on 30.09.15, Russian Maritime Register of Shipping, Saint-Petersburg, Edition 2016.

[30] Smirnov V.I., 1989, Persistent accumulations of ice in the ocean. Polar Geography and Geology, 13, DOI: $10.1080 / 10889378909377409$.

[31] WMO, 2014, Ice chart colour code standard, Version 1.0, WMO/TD-No. 1215, Originally Published 2004, Version 1 May 2014, JCOMM Technical Report No. 24.

[32] WMO, 2004, WMO Sea - Ice Nomenclature Terminology. WMO/OMM/BMO - No.259, Volume 1, Edition 1970 - 2004. 